Sonidos para imaginar: La radio y la ficción

Lía Gómez

IICom - FPyCS - UNLP.

Question/Cuestión, Vol. 2, № 66, Agosto 2020

ISSN 1669-6581

https://perio.unlp.edu.ar/ojs/index.php/question/index

IICom-FPyCS-UNLP

\title{
SONIDOS PARA IMAGINAR: LA RADIO Y LA FICCIÓN
}

SOUNDS TO IMAGINE: RADIO AND FICTION

Lía Gómez / lia.gomez@perio.un|p.edu.ar

http://orcid.org/0000-0002-1377-8167

Docente-Investigadora Facultad de Periodismo y Comunicación Social / UNLP

\section{Palabras Clave}

Sonidos, Radio, Ficción

\section{Key words}

Sounds, Radio, Fiction 
"En la casa de Migré hay una radio a galena en el vestíbulo, otra en la cocina, otra en el dormitorio de los padres y otra más en el patio. En el aparador del comedor está la de válvulas, madera de caoba auténtica, modelo Philips 736A, que queda reservada para las audiciones de música clásica. En el dormitorio del chico hay otra que es un auténtico ejemplar Millateri: no funciona, tiene un componente que venía en la caja, pero no figuraba en el manual de instrucciones y que probablemente sea lo que permite captar aleatoriamente conversaciones de las casas vecinas, jaunque ninguna emisora oficial!" (Liliana

Viola, 2014, p.49).

La cita, extraída del libro prohibido por vericuetos legales y de mitos de ese prócer de la telenovela argentina, me permite en la deriva de la escritura, poner en escena tres cuestiones.

La primera, la materialidad de la radio como objeto de una casa, esos aparatos que son parte de las fotografías, recuerdos, imágenes y sonidos de la infancia. La segunda, el sentido de la escucha, ligado a la música clásica que aparece en la cita, pero también a la rugosidad del sonido de aparatos de distinta capacidad técnica, una sonoridad distinta de la Philips 736A, la Millateri, la que no funciona del todo o sintoniza a lo lejos con ese chirrido característico que cada tanto deja escuchar una voz, una melodía.

La tercera, el valor de los relatos, esas conversaciones de las casas vecinas "de ninguna emisora oficial" pero que Migré las convierte (casi como las conversaciones de las tías de Puig en su literatura) a escenas radiales.

Más conocido por sus telenovelas como "Pobre Diabla" (1973), "Rolando Rivas Taxista" (1974) o "Piel Naranja" (1975), Alberto Migré tuvo en la radio también una época de esplendor. Entre sus producciones podemos mencionar: "Alguien para querer", con Hilda Bernard y Fernando Siro por radio El Mundo. "El 
divorcio", "El precio de ser otra" ambas con Carlos Girini. Mestiza, con Beatríz Taibo y Atilio Marinelli; y años más tarde, "Permiso para imaginar, ciclo de historias unitarias emitidas por Radio Belgrano

Mestiza (Alberto Migré) https://youtu.be/lfzfHWeUW9s

La historia de la radio, es también la tradición de los radioteatros, de actores y actrices argentinas, de revistas de moda, cultura y espectáculo como Radiolandia, Sintonía o Antena. Es la voz que luego se corporiza en imagen de figuras como Zuly Moreno, Tita Merello, Ada Falcón. Francisco Canaro, Irma Córdoba, Ricardo Darín (padre), Hilda Bernard y tantos otros y otras.

Este breve texto, es una invitación a revisitar la radio como espacio de la ficción, a volver a escuchar y ver las imágenes sonoras de todos los tiempos. A comprenderla como escena de géneros diversos, el humor, el drama, el 
suspenso. Pero también, del silencio, el ritmo, los relatos de las desventuras de la vida cotidiana, de la vida, pasión y muerte como inicia el Juan Moreira de Leonardo Favio. De los y las héroes anónimos/as, de personajes y escenas de 100 (cien) años de radio.

\section{Panorama del cine}

En la ciudad de La Plata, Panorama del Cine es un programa emitido por Radio Universidad desde hace más de 50 años. Conducido por Carlos Vallina, es, en sus inicios, parte de los "panoramas de las artes" que emite la emisora de lunes a viernes a las 20:00hs. Censura e interrupción mediante en la dictadura iniciada en 1976, vuelve a principio de los años 80 en su horario de las 21:00hs. Indaga en las formas narrativas que el cine nos proporciona e interviene sobre la escena cultural social y política de cada una de las épocas que nos tocan. Con entrevistas, comentarios, críticas, música e invitados, este programa se convierte en un clásico de la emisora platense. La radio y el cine tienen una larga trayectoria, siendo el mismo programa la voz de la reapertura de la carrera de cinematografía en la ciudad. Recuperamos aquí, a modo de homenaje también a esos cincuenta y pico de años de Panorama del cine, ese cruce entre la ficción, los y las protagonistas, los sonidos y las imágenes de esa cajita misteriosa hoy transformada en el éter digital en el centenario de su primera emisión.

En 1934 estrena "Los ídolos de la radio", dirigida por Eduardo Morera, encuentra entre sus intérpretes a Olinda Bozán, Antonio Podestá, Mario Fortuna, Ada Falcón y Carmen Cárdenas, de la que alguna vez el mismo Migre habría dicho que era la voz más hermosa que jamás había escuchado. 


\section{Los ídolos de la radio (1934)}

https://youtu.be/y9yw51TBwlA

El film, ubica la mirada en el detrás de la escena radial. Compone situaciones en estudio desde un hombre haciendo la voz de un pequeño que cae en llanto, la misma Olinda Bazán actuando frente al micrófono y al mismo tiempo frente a cámara en el personaje de una señora que quiere vender la radio (el aparato) de su casa.

"Han escuchado el episodio 2945, de la novela radial titulada La congoja de una madre, o cuando el dolor aprieta...si le aprietan los zapatos compre calzado doble $x$ es el mejor", se ve y escucha al locutor. Acto seguido, la protagonista cambia el dial y oye: "Señorita, quiere ser usted célebre y ganar 
dinero, inscríbase en el concurso de cancionistas de la radio de esta estación para seleccionar la reina del tango".

En una operación diegética, el aparato transmisor ubica el motivo y la acción de lo que viene en el film, se produce un giro narrativo y la mujer ya no quiere vender la radio, sino ser parte. Ser cancionista como el gran sueño de la época dorada.

La película, producida por la Productora Cinematográfica Argentina Río de la Plata, une a Jaime Yankelevich, Juan Cossio y Francisco Canaro. Este último, reconocido productor de tango, y Jaime Yankelevich empresario de la radio desde sus inicios, que da vida y auge a Radio Belgrano, cadena que años después es parte esencial de la primera emisión de televisión en el país junto a Eva Perón, también actriz de radio, pero esta vez como protagonista de la escena política.

Francisco Canaro además de productor, es un importante compositor, autor de la melodía de "Se dice de mí", con letra del poeta Ivo Pelay, que inmortaliza Tita Merello en el film de Lucas Demare "Mercado de Abasto" en 1954

Mercado de Abasto (Lucas Demare)

https://youtu.be/5-07rNhkAVQ 
Pero además él y Ada Falcón son los protagonistas de un amor de novela (o radio novela) que involucra el mundo del espectáculo y la política, que narra muy bien Sergio Wolf y Lorena Muñoz en "Yo no sé qué me han hecho tus ojos" (2003).

Yo no sé qué me han hecho tus ojos (Sergio Wolf y Lorena Muñoz)

https://youtu.be/hghpYwHkuAU 
El documental de este siglo, recupera el testimonio de una historia de amor, locura, apogeo y ocaso que conserva en la memoria desde la ficción "Idolos de la radio" la única película que Ada Falcón protagoniza.

En el film del 34, podemos recorrer los cánticos, la impostación, los ritmos y tonos que actores y actrices imprimen en el micrófono para la escucha de toda la población, la voz como elemento central de la creación del actor/triz, los imaginarios, los sonidos que quedan en el recuerdo sonoro y sensible de familias enteras que esperan el horario del radioteatro de la tarde. En el del 2003, la voz de Ada Falcón se torna un misterio, una búsqueda de testimonios, recuerdos, y sensaciones de un tiempo otro que se recupera en el presente. 
Dice Ada Falcón en los minutos finales: "Mi gran amor (...) mi gran amor es el recuerdo"

Las voces de las cancionistas, e intérpretes del radioteatro son parte de nuestra cultura popular, como "Nazareno Cruz y el lobo", cuya versión más conocida es la película de Leonardo Favio de 1975, pero que se origina en el radioteatro de Juan Carlos Chiappe, estrenado en Radio del Pueblo en 1951. "Fue en Bahía Blanca. Después de una función. El intendente nos invitó a toda la compañía a pasar la noche en su estancia. Se llama "El Fachinal". Era muy pequeña. De noche el lugar era tétrico. El viento aullaba entre los árboles. Ahí se me ocurrió recrear el lugar y vincularlo a la leyenda del séptimo hijo varón que se convierte en lobo". (Chiappe, 1974)

Nazareno Cruz y Lobo (Leonardo Favio)

https://youtu.be/edMRMEHnJGk 
Juan Carlos, es uno de los autores de radioteatro más conocidos y más olvidados de la historia de la radio, marca una generación de narradores de la cultura, que recupera tradiciones, mitos, fábulas e historias que nos recorren. La leyenda guaraní del hombre que se transforma en lobo bajo la luna llena, se convierte en Favio, bajo su propia versión y la de Zuhair Jury, (su hermano) en una referencia perfecta a la cultura popular. Sus creencias, los santos paganos, las brujas, el amor y la lucha por sobrevivir frente a los avatares de ese territorio que lo articula con el paisaje político del año de su estreno. El diablo gaucho, el pasado y el presente en un joven que revoluciona el destino por amar. Amor a la muchacha como en las historias de radioteatros y novelas, 
pero también amor a la causa de la libertad que busca Nazareno como los jóvenes de los años 70 en períodos convulsionados para el peronismo en argentina. El film, además de un universo de imágenes que desafían el montaje de su tiempo, configura un paisaje sonoro que recupera cada detalle, como en aquellos radioteatros que Favio escucha de chico. En algunos de ellos incluso participa como actor, con guiones de su madre, Laura Favio (Manuela Olivera Garcés), a quien le dedica su última película Aniceto (2007), o en algunos papeles en Radio e Mundo, que entre una cosa y otra lo introduce a la tierra del cine. "El país del cine, no deja de ser tan contradictorio como el cine del país" (Prividera, 2014, p.370)

La película de Favio es una de las más vistas en la historia del cine nacional, y quizás entre tantas causas, una sea, la de ese imaginario maravilloso que este cine recupera del radioteatro como huella de los sonidos para imaginar de la historia de nuestra ficción.

\section{Bibliografía, y filmografía:}

Viola, Liliana (2017) Migré. El maestro de las telenovelas que revolucionó la educación sentimental del país. Sudamericana Prividera, Nicolas (2014) El país del cine. Los Ríos.

Entrevista a Juan Carlos Chiappe disponible en:

http://www.magicasruinas.com.ar/revistero/esto/revdesto180.htm

Los ídolos de la radio (1934) Disponible en:

https://www.youtube.com/watch?v=y9yw51TBwIA

Mercado de Abasto (1954) Disponible en:

https://www.youtube.com/watch?v=K5bWyKJGfRk 
Yo no sé qué me han hecho tus ojos (2003) Disponible en:

https://www.youtube.com/watch?v=ULvNdsh8zPw

Nazareno Cruz y el lobo (1975) Disponible en:

https://www.youtube.com/watch?v=18In3qVbr-0

Mestiza Crónica de un Buenos Aires romántico (radioteatro). Disponible en:

https://www.youtube.com/watch?v=IfzfHWeUW9s\&t=26s 